Cybernetics: Journal Educational Research and Social Studies

Volume 2, Nomor 3, Juli 2021

Journal Homepage: http://pusdikra-publishing.com/index.php/jrss

\title{
Hubungan Intensitas Mengikuti Pembelajaran Akidah Akhlak Dengan Karakter Religius Siswi Di SMK Cerdas Murni Tembung
}

\author{
Hendri Fauza ${ }^{1}$, Asmidar Rohimi Sipahutar ${ }^{2}$
}

Universitas Islam Negeri Sumatera Utara

Corresponding Author : @ hendrifauza@uinsu.ac.id

\begin{tabular}{|c|c|}
\hline & ABSTRACT \\
\hline & $\begin{array}{l}\text { Penelitian ini bertujuan untuk mengetahui: } 1 \text {. Hubungan Intensitas Mengikuti } \\
\text { Pembelajaran Akidah Akhlak di SMK Cerdas Murni Tembung. 2. Karakter } \\
\text { Religius siswa di SMK Cerdas Murni Tembung.3. Hubungan Intensitas } \\
\text { Mengikuti Pembelajaran Akidah Akhlak Dengan Karakter Religius Siswa Di } \\
\text { SMK Cerdas Murni Tembung.Penelitian menggunakan beberapa instrument } \\
\text { metode penelitian yaitu observasi, dokumentasi dan angket.Sedangkan analisis } \\
\text { data penulis menggunakan analisis data kuantitatif yang ditabelkan secara } \\
\text { sistematis dengan menggunakan teknik korelasi product moment. Data yang } \\
\text { diolah menggunakan teknik korelasi product moment memperoleh hasil sebagai } \\
\text { berikut :"dari hasil koefisien product moment dengan }=228,05 \text { yang } \\
\text { dibandingkan dengan } 0,265 \text { pada taraf signifikan } 0,05 \% \text { dari sebanyak } 54 \text { siswa", } \\
\text { maka dapat disimpulkan bahwa terdapat hubungan yang signifikan antara } \\
\text { Intensitas terhadap karakter religius siswa di SMK Cerdas Murni Tembung }\end{array}$ \\
\hline ata Kunci & Pembelajarann, Intensitas, Religius, Akidah Akhlak \\
\hline
\end{tabular}

\section{PENDAHULUAN}

Pada era globalisasi pada saat ini membawa masyarakat Indonesia melupakan pendidikan karakter pada anak bangsa. Padahal pendidikan karakter ini merupakan suatu pondasi bagi bangsa yang sangat penting dan perlu dibutuhkan danditanamkan sejak dini kepada anak-anak.

Sasaran pendidikan adalah membentuk karakter, sedangkan tujuan utama pendidikan bukanlah pengetahuan tetapi penampilan atau tindakan oleh karena itu pendidikan karakter terhadap anak-anak pada zaman ini sangatlah dibutuhkan agar anak-anak bangsa lebih baik lagi pada karakter mereka masing-masing.

Membicarakan karakter merupakan hal yang sangat penting dan mendasar. Karakter adalah mustika hidup yang akan membedakan manusia dengan binatang, karena manusia tanpa karakter adalah manusia yang sudah membinatang. "orang yang berkarakter kuat dan baik secara individual maupun sosialialah mereka yang memiliki akhlak, moral, dan budi pekertiyang baik, mengingat begitu urgennya karakter, maka insititual pendidikan memiliki tanggung jawab untuk menanamkan nya melalui 
proses pembelajaran. Maka karakter sangat lah penting bagi peserta didik, dengan terbentuknya karakter pada diri mereka sendiri mereka akan menjadi peserta didik yang budi pekerti (Zubaedi, 2011).

Penguatan pendidikan karakter dalam konteks sekarang sangatlah relevan untuk mengatasi krisis moral yang sedang terjadi di Negara kita. Karena sudah diakui saat ini sangat terjadi krisis yang begitu nyata dan sangat mengkhawatirkan dalam masyarakat dengan melibatkan milik kita yang paling berharga, yaitu anak-anak. Krisis itu antara lain dengan meningkatnya pergaulan seks bebas, maraknya angka kekerasan,

Karena akar dari semua tindakan yang jahat dan buruk, tindakan kejahatan, karena sudah hilangnya karakter. Karakter yang kuat yaitu pandanganfundamental yang memberikan kemampuan kepada populasi manusia untuk hidup bersama dalam kedamaian serta membentuk dunia yang dipenuhi dengan kebaikan, yang bebas dari kekerasan dan tindakantindakan yang tidak bermoral.

Menurut Sudarminta, praktek pendidikan yang semestinya memperkuat aspek karakter atau nilai-nilai kebaikan sejauh ini hanya mampu menghasilkanberbagai sikap dan perilaku manusia yang nyata-nyata malah bertolak belakang dengan apa yang diajarkan. Dicontohkan bagaimana pendidikan moral pancasila (PMP) dan agama pada masa lalu merupakan dua jenis mata pelajaran tata nilai, yang ternyata tidak berhasilmenanamkan jumlah nilai moral dan humanisme kedalam pusat kesadaran siswa, dengan kata lain aspek-aspek lain yang ada pada diri siswa, yaitu aspek afektif dan kebijakan moral yang kurang mendapatkan perhatian.Koesoema menegaskan bahwa persoalan komitmen dalam mengintegrasikan pendidikan dan pembentukan karakter merupakan titik lemah kebijakan pendidikan nasional.

Atas kondisi demikian, semua orang sepakat mengatasi persoalan kemerosotan dalam dimensi karakter ini. Para pembuat kebijakan, dokter, pemuka agama, pengusaha, pendidik, orangtua, dan masyarakat umum, semua menyuarakan kekhawatiran yang sama (Zubaedi, 2011).

Kita memang harus khawatir. Setiap hari, berita berisi tragedi yang mengejutkan dan statistik mengenai anak-anak membuat kita tercengang, khawatir, dan berusaha, mencari jawaban atas persoalan tersebut.Sejauh ini kekhawatiran terbesar kita yaitu tindakan kekerasan yang dilakukan anak-anak muda, dan itu sudah merupakan keadaan gawat yang perlu segera diatasi.Kajian-kajian ilmiah tentang perilaku tidak terpuji yang dilakukan siswa dalam pendidikan di Indonesia sangat terbatas. Indikator lain yang kita khawatirkan juga dapat terlihat pada sikap kasar anak-anak yang lebih kecil, 
mereka semakin kurang rasa hormat nya terhadap orang tua, guru dan sosok lainnya yang berwenang, tingkah laku yang buruk semakin meningkat, kekerasan yang bertambah, kecurangan yang meluas, dan sipat kebohongan yang semakin lumrah. Peristiwa ini sangat mencemaskan bagi kita, dan sebagian orang tua mulai mengirim anaknya ke sekolah khusus, sementara sebagian lagi mendidik anaknya di rumah saja.

Emosi karakter dan perilaku yang tidak terpuji yang menerpa siswa sebagaiamana tersebut di atas merupakan gejala umum yang berlaku dimanamana, termasuk di Indonesia. Jika ditanyakan kepada orang tua di Indonesia rasanya memiliki kekhawatiran dan kecemasan yang sama setelah mencermati fenomena kemerosotan karakter atau moral di kalangan anak-anak remaja. Dapat diakui persoalan karakter atau moral tidak sepenuhnya terabaikan oleh lembaga pendidikan.Akan tetapi, dengan fakta-fakta seputar kemerosotan karakter pada sekitar kita menunjukkan bahwa ada kegagalan pada institusi pendidikan kita dalam hal menumbuhkan manusia Indonesia yang berkarakter atau berakhlak mulia. Hal ini karena apa yang diajarkan disekolah tentang pengetahuan agama dan pendidikan moral belum berhasil untuk membentuk manusia yang benarbenar berkarakter.

Selain itu dalam masa-masa ini penuh persoalan seperti sekarang ini, dimana orang tua itu harus perlu berusaha keras dalam ikut mendidik karakter ataupun moral anak-anaknya agar mereka bisa berfikir, bersikap baik, bertindak sesuai norma-norma agama. Pendidikan karakter perlu dimulai dengan penanaman pengetahuan dan kesadaran kepada anak akan bagaimana bertindak sesuai nilai-nilai moralitas, sebab jika anak tidak tahu bagaimana bertindak dengan baik, maka perkembangan moral mereka akan terganggu, lagi pula sudah kita ketahui bahwa karakter itu dapat dilihat dari "Tindakan bukan hanya dari pemikiran". Karakter sesorang yang positif atau mulia akan menjadikan mengangkat status derajat yang tinggi dan mulia bagi dirinya sendiri. Kemuliaan seseorang terletak pada karakternya yang baik.

Situasi dan kondisi karakter bangsa yang sedang memprihatinkan telah mendorong pemerintah untuk mengambil inisiatif untuk memprioritaskan pembangunan karakter bangsa. Pembangunan karakter bangsa dijadikan arus utama pembangunan nasional. Hal ini mengandung arti bahwa setiap upaya pembangunan harus selalu di arahkan untuk memberi dampak positif terhadap pengembangan karakter.

Sekolah adalah tempat yang strategis bahkan tempat yang utama sesudah keluarga dalam membentuk karakter religius siswa disekolah. Bahkan sudah 
seharusnya menjadikan kualitas akhlak dan karakter sebagai salah satu Quality Assurance yang harus dimiliki oleh setiap lulusan sekolahnya. Sudah pasti kita berharap siswa yang kita didik disekolah menjadikan hamba Allah yang beriman.

Jika ternyata baiknya akhlak menjadikan sempurnanya iman seseorang, maka tidak ada alasan lagi bagi sekolah untuk menomorduakan keseriusan dalam upaya pembentukan akhlak dan karakter religius dibandingkan keseriusan mengajar keunggulan tentang teknologi. Bahkan bisa kita yakini jika peserta didik kita ini memiliki akhlak dan karakter yang baik, maka Insya Allah mereka pun akan lebih mudah untuk kita pacu mengejar prestasi lainnya.

Perlu kita ketahui membentuk karakter itu tidak semudah memberi nasehat terhadap anak, tidak semudah memberikan instruksi, tetapi memerlukan kesabaran, pembiasaan, dan pengulangan, Sehingga proses pendidikan karakter merupakan keseluruhan proses pendidikan yang di alami siswa sebagai pengalaman pembentukan kepribadian melalui memahami dan mengalami sendiri nilai-nilai, keutamaan-keutamaan moral, nilai-nilai keagamaan.

Kenyataanya yang ditemui oleh peneliti di lapangan bahwa peserta didik itu memiliki beragamperilaku dan karakter.Ada yang terpuji dan ada yang tercela.Seperti dalam perkataan dan pergaulan banyak didapati bahasa yang tidak sopan dan tidak seharusnya, mengumpat, mencaci-makisesamateman, bukanlah hal yang terpuji. Padahal ketika peneliti melihat proses kegiatan belajar mengajar pada mata pelajaran akidah akhlak ini justru siswa yang seperti itu yang mendapatkan nilai tinggi, jika dilihat dari kegiatan belajar mengajar bahwa siswa yang berkelakuan baik yang mendapat nilai biasa-biasa saja.

Hal ini berlainan dengan harapan bahwa seharusnya siswa yang mendapatkan nilai bagus dalam pembelajaran akidah akhlak itu mestinya siswa yang berprilaku dan karakternya harus baik seperti didapati sewaktu kegiatan belajar mengajar, siswa yang berkarakter kurang baik akan dipahami jika nilai dalam pembelajaran akidah akhlak juga tidak baik. Namun yang terjadi bahwa ada siswa yang mendapat nilainya bagus dan perilaku nya buruk sedang siswa yang baik mendapat nilai kurang baik sementara memiliki sifat dan karakter yang baik.

Pendidikan merupakan bidang yang sangat penting bagi kehidupan manusia, pendidikan dapat mendorong peningkatan kualitas manusia dalam membentuk meningkatnya kompotensi kognitif, afektif, maupun psikomotor. Masalah yang dihadapi dalam upaya memperbaiki dan 
meningkatkan kualitas kehidupan sangat kompleks, banyak faktor yang harus dipertimbangkan karenapengaruhnya pada kehidupan manusia tidak dapat diabaikan yang jelas disadari bahwa pendidikan merupakan salah satu faktor yang dapat meningkatkan kualitas sumber daya manusia pada suatu bangsa. Bagi suatu bangsa pendidikan merupakan hal yang sangat penting, karena dengan pendidikan manusia juga akan mampu berpotensi dengan lingkungan. Oleh karena itu membangun pendidikan menjadi suatu keharusan, baik dilihat dari persfektif internal maupun eksternal.

Menurut Nurcholis, religius ini bukanlah hanya sekedar shalat dan membaca do'a. Agama lebih dari itu, yaitu keseluruhan tingkah laku manusia yang terpuji yang dilakukan demi memperoleh ridho dari Allah SWT.

Karakter religius ini memang harus benar-benar ditanamkan kepada siswa. Dalam proses pembentukan karakter religius siswa tidak akan berlangsung dengan sendirinya, tanpa bantuan dari orang lain, akan tetapi proses tersebut dapat dipengaruhi oleh lingkungan sekolah. Segala peristiwa yang terjadi di dalam sekolah semestinya dapat diintegrasikan dalam program pendidikan karakter, dari situlah pendidikan karakter merupakan suatu usaha bersamaan dari seluruh warga untuk sekolah yang dapat menciptakan sebuah kultur yang baru disekolah, yaitu kultur pendidikan nilai karakter.

Penerapan pendidikan karakter religius sekarang ini mutlak diperlukan bukan hanyadisekolah saja, tetapi di rumah dan lingkungan sosial juga. Bahkan sekarang ini bukan hanya anak usia dini hingga remaja, tetapi juga di usia dewasa, karena pendidikan karakter religius ini mutlak diperlukan demi kelangsungan bangsa ini. Karakter religius ini dapat dibentuk melalui proses. Salah satu proses tersebut dapat melalui pendidikan. Untuk membentuk pribadi religius tersebut dapat melalui kebiasaan-kebiasaan yang baik dan bermanfaat yang dilakukan secara berulang-ulang, karena lambat laun semua akan masuk pada bagian pribadinya yang sulit ditinggalkan.

Berpijak dari asumsi maupun gambaran yang telah diuraikan dari atas maka peneliti tertarik untuk mengkaji lebih lanjut yang tertuang dalam judul "Hubungan Intensitas Mengikuti Pembelajaran Akidah Akhlak Dengan Karakter Religius Siswa di SMK Cerdas Murni Tembung"

\section{METODE PENELITIAN}

Penelitian ini dilakukan di SMK Cerdas Murni Tembung Kecamatan Percut Sei Tuan kabupaten Deli serdang Provinsi Sumatera Utara, dilakukan pada tanggal 3 September 2020 sampai 12 September 2020. Instrumen pengumnpulan data yang digunakan adalah Angket (Kuesioner) dan 
Cybernetics: Journal of Research and Educational Studies

Volume 2 Nomor 3, Juli 2021

Halaman 73-83

Dokumentasi. Adapun teknik analisis data yang digunakan dengan melakukan uji Deskriptip Data, Uji Persyaratan Analisis, Pengajuan Hipotesis. Teknik analisis data merupakan cara yang digunakan untuk menguraikan keteranganketerangan atau data yang diperoleh agar data tersebut dapat dipahami bukan oleh orang yang mengumpulkan data saja, tapi juga oleh orang lain.Setelah data penelitian kuantitatif terkumpul, langkah selanjutnya yang harus dilakukan adalah melakukan penskoran atau mengubah data tersebut kedalam bentuk angka-angka kuantitatif.Metode ini menggunakan statistik yang merupakan alat bagi peneliti untuk mengorganisasikan dan menafsirkan angka-angka yang diperoleh dari pengukuran terhadap variabel. (Sugiyono, 2020)

\section{HASIL DAN PEMBAHASAN}

\section{Hasil Uji Deskriptif Intensitas (Variabel X)}

Data variabel $X$ yaitu hubungan intesnitas mengikuti pembelajaran akidah akhlak diperoleh dengan menggunakan angket yang diberikan kepada seluruh siswa kelas XI. Angket diberikan untuk mengetahui intensitas siswa mengikuti pembelajaran akidah akhlak yang dilakukan oleh siswa SMK Cerdas Murni

Tabel 1

Tabulasi Data Variabel X ( Intensitas)

\begin{tabular}{|c|c|c|c|c|c|}
\hline No & $\mathbf{X}$ & Frekuensi & Presentasi Kumulatif & FX & $\boldsymbol{F X}^{\mathbf{2}}$ \\
\hline 1 & 74 & 1 & $1,9 \%$ & 74 & 148 \\
\hline 2 & 76 & 2 & $3,7 \%$ & 152 & 304 \\
\hline 3 & 77 & 3 & $5,6 \%$ & 231 & 462 \\
\hline 4 & 78 & 8 & $14,8 \%$ & 624 & 1248 \\
\hline 5 & 79 & 4 & $7,4 \%$ & 316 & 632 \\
\hline 6 & 80 & 13 & $24,1 \%$ & 1040 & 2080 \\
\hline 7 & 81 & 11 & $20,4 \%$ & 891 & 1638 \\
\hline 8 & 82 & 5 & $9,3 \%$ & 410 & 820 \\
\hline 9 & 83 & 4 & $7,4 \%$ & 332 & 664 \\
\hline 10 & 84 & 2 & $3,7 \%$ & 168 & 336 \\
\hline 11 & 87 & 1 & $1,9 \%$ & 87 & 174 \\
\hline Jumlah & 54 & $100 \%$ & 4325 & 8506 \\
\hline
\end{tabular}

Dari perhitungan tersebut diketahui bahwa banyak kelas interval adalah 7, panjang kelas berjumlah 2, dan standar deviasinya 2.292. Nilai rata-rata intensitas di SMK Cerdas Murni Tembung adalah 37,87nilai rata-rata tersebut diinterprestasikan dengan tabel kualitas intensitas rata-rata intensitas di SMK Cerdas Murni Tembung sebesar 37,87 cukup baik. Dari data di atas dapat dilihat bahwa tingkat intensitas siswa berbeda. Terdapat 3 siswa yang memiliki intensitas yang memilikisangat rendah, 11 siswa yang memiliki intenistas 
Cybernetics: Journal of Research and Educational Studies

Volume 2 Nomor 3, Juli 2021

Halaman 73-83

rendah, dan 4 siswa yang memiliki intensitas sedang, dan 13 siswa yang memiliki intensitas tinggi, dan 23 siswa yang memiliki intensitas sangat tinggi.

\section{Hasil Uji Deskriptif Pengembangan Sikap Spiritual Siswa (Variabel Y)}

Data variabel intensitas siswa diperoleh dengan menggunakan angket yang diberikan kepada siswa. Angket diberikan dengan tujuan untuk mengetahui intensitas yang dimiliki oleh siswa-siswi SMK Cerdas Murni Tembung . Hasil yang diperoleh dari data tersebut selanjutnya peneliti sajikan dalam bentuk tabel dan disajikan untuk menginformasikan mean, varians, dan standar deviasi.

Tabel 2

Tabulasi Data Variabel Y (Karakter Religius )

\begin{tabular}{|c|c|c|c|c|c|}
\hline No & Y & F & Frekuensi Kumulatif & YF & FX $^{2}$ \\
\hline 1 & 83 & 2 & $3,7 \%$ & 166 & 27.556 \\
\hline 2 & 84 & 1 & $1,9 \%$ & 84 & 7.056 \\
\hline 3 & 85 & 4 & $7,4 \%$ & 340 & 115.600 \\
\hline 4 & 86 & 6 & $11,1 \%$ & 516 & 266.256 \\
\hline 5 & 87 & 4 & $7,4 \%$ & 348 & 121.104 \\
\hline 6 & 88 & 9 & $16.7 \%$ & 792 & 627.264 \\
\hline 7 & 89 & 9 & $16,7 \%$ & 801 & 641.601 \\
\hline 8 & 90 & 9 & $16,7 \%$ & 810 & 656.100 \\
\hline 9 & 91 & 6 & $11,1 \%$ & 546 & 298.116 \\
\hline 10 & 92 & 2 & $3,7 \%$ & 184 & 33.856 \\
\hline 11 & 93 & 2 & $3,7 \%$ & 186 & 34,596 \\
\hline \multicolumn{2}{|c|}{ Jumlah } & 54 & $100 \%$ & 4.773 & 2829105 \\
\hline
\end{tabular}

Berdasarkan rekapitulasi data karakter religius yang di dapat dari angket maka dapat diketahui bahwa nilai item terendah dari pengisian angket terendah adalah 83 dan yang tertinggi adalah 93 dengan total keseluruhan 4773. Dari perhitungan tersebut diketahui bahwa banyak kelas interval adalah 7 , panjang kelas berjumah 1, variansi 1527 dan standar deviasinya 239. Dari perhitungan tersebut diketahui bahwa nilai rata-rata intensitas siswa di SMK Cerdas Murni Tembung 40,48Nilai rata-rata tersebut diinterpretasikan dengan tabel kualitas intensitas untuk mengetahui kualitasnya. Diketahui bahwa rata-rata karakter religius siswa di SMK Cerdas Murni Tembung sebesar 40,48terletak pada interval 80-100 dalam kategori sangat baik. Setelah data di atas disajikan dalam bentuk tabel distribusi frekuensi yang telah diketahui kualitasnya, hasil tersebut kemudian divisualisasikan dalam bentuk histogram sebagai berikut : Dari data di atas dapat dilihat bahwa tingkat sikap spiritual siswa berbeda. Terdapat 3 siswa yang memiliki karakter religius yang sangat rendah, 10 siswa yang 
Cybernetics: Journal of Research and Educational Studies

Volume 2 Nomor 3, Juli 2021

Halaman 73-83

memiliki tingkat rendah, 13 siswa yang memiliki sedang, 18 siswa yang memiliki karakter religius yang tinggi, dan 10 siswa yang memiliki karakter religius yang sangat tinggi.

\section{Uji Persyaratan Analisis}

Dalam proses analisis lanjut perlu dilakukan uji persyaratan data yang meliputi : data bersumber dari sampel yang telah dipilih, sampel berasal dari populasi yang berdistribusi normal dan kelompok data mempunyai variansi yang homogen. Pada Bab ini akan dilakukan pengujian persyaratan analisis normalitas dan homogenitas dari distribusi data yang diperoleh.

\section{Uji Normalitas}

Uji normalitas bertujuan untuk menguji apakah dalam model regresi, variabel residual memiliki distribusi normal.Pada penelitian ini uji normalitas dilakukan menggunakan perangkat lunak SPSS dengan uji statistik KolmogorovSmirnov (K-S). Hasil uji K-S

Tabel 3

One-Sample Kolmogorov-Smirnov Test

\begin{tabular}{|ll|r|r|}
\hline & & $\begin{array}{r}\text { Intensita } \\
\text { s }\end{array}$ & \multicolumn{2}{|c|}{ Religius } \\
\hline $\mathrm{N}$ & & 54 & 54 \\
Normal & Mean & 80.09 & 88.39 \\
Parametersa,b & Std. & 2.292 & 2.390 \\
& Deviation & .151 & .121 \\
Most & Absolute & .124 & .082 \\
Extreme & Positive & -.151 & -.121 \\
Differences & Negative & .151 & .121 \\
Test Statistic & & $.004 \mathrm{c}$ & $.049 \mathrm{c}$ \\
Asymp. Sig. (2-tailed) &
\end{tabular}

a. Test distribution is Normal.

b. Calculated from data.

c. Lilliefors Significance Correction.

Berdasarkan Tabel di atas hasil dari analisis Kolmogorov-Smirnov Test, menunjukkan bahwa nilai signifikan dari masing-masing variabel yaitu, kegiatan ekstrakurikuler Intensitas $(X)$ Sign 0,04 dan variabel pengembangan Karakter Religius siswa $(\mathrm{Y})$ Sign 0,49, dimana nilainya lebih besar dari a $=0,05$ $($ Asym Sign $=0,04>0,05$ dan (Asyms Sign $=0,49>0,05)$, maka data tersebut berdistribusi secara normal.

\section{Hasil Uji Homogenitas}

Pengujian homogenitas data dilakukan untuk mengetahui apakah kelompok sampel yang digunakan dalam penelitian ini berasal dari populasi 
yang homogeni atau tidak, artinya apakah sampel yang digunakan dapat mewakili seluruh populasi yang ada. Pengujian homogenitas ini menggunakan perangkat lunak SPSS dengan hasil sebagai berikut :

$$
\begin{aligned}
& \mathrm{F}_{\text {hitung }}=\frac{S 2 \text { besar }}{\text { s2 kecil }}=\frac{\text { Varian Terbesar }}{\text { Varian Terkecil }} \\
& =\frac{1527}{1527}=1
\end{aligned}
$$

Untuk menghitung $\mathrm{F}_{\text {tabel }}$ diperoleh dari daftar nilai kritis pada distribusi $\mathrm{F}_{\text {tabel }}$ dengan dk pembilang $=(54-1), \mathrm{dk}$ penyebut $=(54-1)$ dan taraf nyata $\propto 0,05$ diperoleh $F_{0,05}(35,35)=0,265$, karena $F_{\text {hitung }}>F_{\text {tabel }}$ yakni 1 $>0,265$ maka dapat disimpulkan bahwa varians dua data variabel tersebut adalah homogen

\section{Pembahasan Hasil Penelitian}

Menjawab rumusan masalah yang pertama telah diketahui bahwa intensitas siswa di SMK Cerdas Murni tembung sangat baik. Hal ini terlihat dari angket yang telah peneliti sebarkan kepada seluruh anggota SMK Cerdas Murni Tembung yang memperoleh nilai rata rata sebesar 37, 87 dengan kategori cukup baik.

Kemudian menjawab rumusan masalah yang kedua yaitu tentang karakter religius siswa di SMK Cerdas Murni Tembung juga sangat baik. Hal ini dapatdibuktikan melalui angket yang telah peneliti sebarkan kepada seluruh siswa kelas XI SMK cerdas murni tembung yang memperoleh nilai rata-rata sebesar 40,48dengan kategoricukup baik. Hal ini membuktikan bahwa siswasiswi memiliki karakter religius yang sangat baik. Selanjutnya, berdasarkan uji hipotesis melalui rumus product moment menunjukkan bahwa terdapat korelasi yang kuat antara intensitas dengan karakter religius siswa di SMK Cerdas Murni Tembung MAN 1, yaitu sebesar 78,96 dan termasuk kategori sangat kuat. Peneliti juga melihat bahwa hubungan intensitas dengan karakter religius siswa di SMK Cerdas Murni memiliki hubungan yang signifikan. Hal ini dibuktikan melalui rumus uji $t$ yang menunjukkan bahwa $t_{\text {hitung }}$ lebih besar dari $t_{\text {tabel, }}$ yaitu 228,05> 0,265. Dari hasil perhitungan tersebut menunjukkan H0 ditolak dan Ha diterima. Kenyataan di atas, mengindikasikan bahwa karakter religius siswa SMK Cerdas Murni Tembung ditentukan oleh intensitas sebesar 79,3881\%. Sedangkan 20,6119\% lainnya ditentukan oleh faktor pendukung lain misalnya pembelajaran di kelas, pembelajaran dari orang tua di rumah, lingkungan sekitar.

\section{KESIMPULAN}

Dari hasil pengolahan dan analisis terhadap data penelitian, maka dapat dikemukakan beberapa kesimpulan sebagai berikut : 
Cybernetics: Journal of Research and Educational Studies

Volume 2 Nomor 3, Juli 2021

Halaman 73-83

1) Berdasarkan data angket intensitas yang diberikan kepada 54 siswa, diperoleh nilai tertinggi yaitu 87 dan nilai terendah yaitu74, dengan demikian peneliti menyimpulkan bahwa intensitas di SMK Cerdas Murni Tembung adalah baik dengan nilai rata-rata yang diperoleh sebesar 37,87.

2) Berdasarkan data angket karakter religius yang diberikan kepada 54 siswa, ditemukan bahwa nilai tertinggi yaitu 93 dan yang terendah yaitu 83, dengan demikian peneliti menyimpulkan bahwa karakter religius siswa adalah baik dengan nilai rata-rata yang diperoleh sebesar40,48.

3) Adanya hubungan yang signifikan antara intensitas terhadap karakter religius siswa di SMK Cerdas Murni Tembung. Hal ini dapat dilihat dari perolehan $r_{\text {hitung }}>r_{\text {tabel }}=1>0.265$ dengan tarafsignifikan 95\% (kepercayaan $95 \%$ atau $a=0,05$ dan derajat kebebasan N-1 = 53 dari (54-1). Maka koefisien korelasi ini jika diinterpretasikan nya itu dapat dikategorikan kuat tingkat hubungannya Berdasarkan uji $\mathrm{t}$ diperoleh nilai $\mathrm{t}_{\text {hitung }}=228,05$ pada taraf signifikan 95\% atau $\mathrm{a}=0,05 \mathrm{dan} \mathrm{dk}=\mathrm{N}-2=52$ (54-2) dari daftar nilai persentil untuk distribusi $t$ diperoleh nilai $t_{\text {table }}$ adalah 1,666. Dikarenakan nilai $t_{\text {hitung }}>t_{\text {tabel }}$ yaitu 228,05> 86 0,794 sehingga $\mathrm{H}_{0}$ ditolak dan $\mathrm{H}_{\mathrm{a}}$ diterima sehingga dapat kita simpulkan bahwa terdapat hubungan yang signifikan antara intensitas dengan karakter religius siswa di SMK Cerdas Murni Tembung.

\section{DAFTAR PUSTAKA}

Zubaedi, (2011) Desain Pendidikan Karakter, (Jakarta : Kencana Prenada Media Group).

Kurniawan Sidik, Pengaruh Intensitas Mengikuti Kegiatan Keagamaan Terhadap Kepribadian Siswa Kelas XI SMA 2 Wonosobo.Institut Agama Islam Negeri Walisongo Semarang, 2009.

Samani, (2012), Konsep dan Model Pendidikan Karakter, (Bandung : PT Remaja Rosdakarya).

Suyadi, (2013), Strategi Pembelajaran Pendidikan Karakter,( Bandung : PT Remaja Rosdakarya ).

Ridwan, Pembentukan Karakter Religius Siswa Berbasis Pendidikan Agama di SMK Negeri 2 Malang , Universitas Muhammadiyah Malang. 2018.

Azizah Nurul Tsalis, Pembentukan Karakter Religius Berbasis Pembiasaan dan Keteladanan di SMA Sains Al-Qur'an Wahid Hasyim, Uin Sunan Kalijaga Yogyakarta , 2017.

Pyiyani Arum Yuliana, Hubungan Intensitas Mengikuti Pembinaan Keagamaan Dengan Sikap Tawadhu Siswa di MTs Sudirman Tahun Ajaran 2014/2015, IAIN Salatiga, 2015. 
Cybernetics: Journal of Research and Educational Studies

Volume 2 Nomor 3, Juli 2021

Halaman 73-83

KhoiriyahMufidatul, Pengaruh Pembelajaran Akidah Akhlak Terhadap Pembentukan Karakter Religius Siswa di SMK Ma'arifNU Mantup, Universitas Islam Negeri Maulana Malik Ibrahim Malang, 2018.

Suharsimi Arikunto, Prosedur Penelitian Suatu Pendekatan Prakter, ( Jakarta : Rineka Cipta).

Nurmawati, (2016), Evaluasi Pendidikan Islami, (Bandung: Ciptapustaka Media).

Ghony Junaidi, (2009), Metodologi Penelitian Pendekatan Kuantitatif, Malang.

Kurniawan Samsul,(2013) Pendidikan Karakter, Yogyakarta : Ar-ruz Media.

Hajar Ibnu, (1996), Dasar-dasar Metodologi Penelitian Kuantitatif Dalam Pendidikan, ( Jakarta : Raja Grafindo Persada).

Iqbal Hasan, (2004), Analisis Data Penelitian Dengan Data Statistik, ( Jakarta : PT Bumi Aksara).

Margono, (2001), Metodologi Penelitian, (Jakarta : Asvi Mahastya).

Sugyono, (2008), Metode Penelitian Kuantitatif, Kualitatif, (Bandung : Alfabeta).

Arikunto, Suharsimi, ( 2010 ), Prosedur Penelitian, Jakarta ; ( Rineka Cipta ).

Neliwati, Metodologi Penelitian Kuantitatif, (Medan, CV. Widya Puspita, 2018).

Azwar, Syaifuddin, (2007), Metode Penelitian, Yogyakarta : Pustaka Belajar.

Kesuma, Dharma, Pendidikan Karakter Kajian Teori dan Praktek di Sekolah,Bandung :PT. Remaja Rosdakarya.

Majid, Abdul dan Dian Andayani,(2012), Pendidikan Karakter Persfektif Islam, Bandung : PT. Remaja Rosdakarya.

Margono, (1997), Metode Penelitian,Jakarta : PT. Rineka Cipta.

Megawangi, Ratna, (2004), Pendidikan Karakter,Jakarta : Indonesia Heritage Foundation.

Noor, Juliansyah, (2012), Metodologi Penelitian, Jakarta : Kencana.

Sugiyono. (2020). Metode Penelitian Pendidikan. Alfabeta.

Zaini, M. F. (2019). The Implementation Of Learning Management In Class VIII Madrasa Tsanawiyah Islamiyah (Mts) Ypi Batangkuis. International Conference on Islamic Educational Management (ICIEM). https:/ / scholar.google.co.id/ citations?user=9xE516oAAAAJ\&hl=id\#d=gs _md_cita$\mathrm{d} \& \mathrm{u}=\%$ 2Fcitations\%3Fview_op\%3Dview_citation \%26hl\%3Did\%26user\%3 D9xE516oAAAAJ\%26citation_for_view\%3D9xE516oAAAAJ\%3Au5HHm VD_uO8C\%26tzom\%3D-420 